\title{
Genetic Variability for Some Quantitative Characters in Gladiolus (Gladiolus grandiflorus L.)
}

\author{
Pushpendra Verty*, V.M. Prasad, J.P. Collis and Manoj Nazir \\ Department of Horticulture, Sam Higginbottom University of Agriculture, Technology and \\ Sciences, Allahabad, U.P., India \\ *Corresponding author
}

\section{A B S T R A C T}

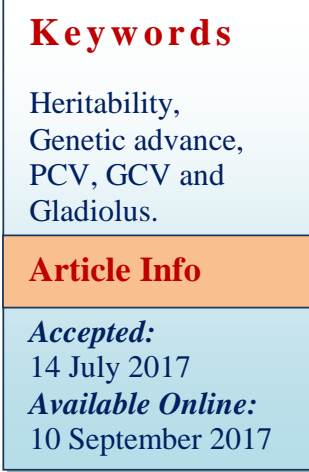

The present investigation was conducted at Field Experimentation Centre, Department of Horticulture, Naini Agriculture Institute, SHUATS, Allahabad during 2013-2014 to assess the variability, heritability, and genetic advance of 20 genotypes for eighteen quantitative characters in gladiolus. Phenotypic coefficients of variation (PCV) and genotypic coefficients of variation (GCV) for all the characters under study ranged from 4.73 to 56.94 percent and 3.84 to 56.64 percent respectively. PCV was higher than the respective GCV for all the characters under study indicating high degree of environmental influence. The heritability of different quantitative characters varied from 32.00 (diameter of corms $\mathrm{cm}$ ) to 99.1 percent (cormels per plant). The high heritability coupled with high genetic advance (percentage of mean) for cormels/plant (99.1 and 116.29 respectively) advocated high genetic progress for this character.

\section{Introduction}

Gladiolus is an important bulbous ornamental prized for its beautiful spikes as well as longer vase -life and said to be the Queen of bulbous flower crops (Panday et al., 2010). The crop has wide range of varietal wealth which exhibits a huge range of variability. Genetic variability is an essential component of any breeding programme, design to improve the characteristics of crop. Generally the estimates of heritability of characters are environment specific (Shimelis and Rhandzu 2010) and should be incorporated in and specifically applied only to the population and environment sampled. Thus selection of characters based on heritability and genetic advance as per cent of mean is of great importance to the breeder for making criteria for improvement in a complex character. The objective of the present study was to quantify the value of genetic variability, heritability and genetic advance for different quantitative characters in the gladiolus genotypes and to identify important quantitative traits to provide information for developing high yielding gladiolus genotypes.

\section{Materials and Methods}

The present investigation entitled "Genetic variability and stability analysis for some 
quantitative characters in gladiolus (Gladiolus grandiflorus L.)" is undertaken to obtain information on genetic variability, heritability, correlation, and stability under four environments. The experiment was conducted during 2013 to 2014 at Department of Horticulture, Naini Agriculture Institute, Shuats, Allahabad.

The experiment was laid out in RBD with three replication.the experiment consisted of twenty treatments namely (Redginger, American beauty, Charm flow, green bay, Jester, Red majestry, Candy man, Summer sunshine, Poppytears, Punjab dawn, Pusa srijana, Arti. Hunting song, Sabnam, Darsan, Arka amar, Legent, summer rose, Wind song and Monini).

The standard statistical procedures were followed for calculating estimates of variability (Burton and De vane 1953). Heritability and genetic advance as per cent of population mean were determined as per the formulae suggested by Burton and De Vane (1953) and Johnson et al., (1955) respectively.

\section{Coefficient of variance}

The coefficient of variance will be cal. By Burton \& Devane (1953) formula phenotypic coefficient of variance (PCV)

$$
\begin{aligned}
& \text { Phenotypic S.d } \\
& \operatorname{PCV}(\%)=\frac{-----------}{\text { General Mean }} 100 \\
& \text { GCV \% }=\frac{\text { Genotypic s.d }}{\text { General Mean }}
\end{aligned}
$$

\section{Heritability in broad sense $\left(\% h^{2}\right)$}

$\left(\% h^{2}\right)$ Heritability will be calculated according to the formula suggested by Allard (1960).

$$
H=\% h^{2}=\frac{\sigma^{2} g}{\sigma^{2} p}
$$

Where, $\mathrm{H}=$ Heritability Coefficient (in broad sense) $\sigma^{2} g \& \sigma^{2}$ p are genotypic \& phenotypic variance respectively.

\section{Genetic advance}

The expected genetic advance will be cal. by Allard's formula - 1960

$\mathrm{GA}=(\mathrm{k})(\sigma \mathrm{p})(\mathrm{H})$

Where $\mathrm{k}=$ selection differential constant, the value of which is 2.06 at $5 \%$ selection intensity.

$\sigma \mathrm{p} \quad=\quad$ Phenotypic s.d

$\mathrm{H}=$ Heritability Coefficient

Genetic Adv.

Genetic Adv. as \% of mean = ----------- x 100

General Mean

\section{Results and Discussion}

Wide range of genotypic coefficient of variation (GCV) was observed for the quantitative characters ranging from (56.64) for cormels per plant to (3.84) days to heading.

High magnitude of (GCV) were recorded for comrles per plant (56.64), followed by shoot per plant and corms per plants (34.46), days to sprouting (20.25), florets open at first (18.37), weight of corms (18.00), florets per spike (17.26), durability of whole spikes (16.19), plant height $(13.96 \mathrm{~cm})$, florets remaining open at a time (13.10), rachis length $(10.00 \mathrm{~cm})$, diameter of first floret (9.54), leaves per shoots (8.36), days to first florets colour showing (5.33), diameter of 
comrs $(4.91 \mathrm{~cm})$, days to first floret opening (4.83), where low estimates were observed for days to last florets opening (4.70). Rashmi and Sanjay Kumar et al., (2014) and Raj, D. R. L. and Raj, D. (1996).

Wide range of phenotypic coefficient of variation (PCV) was observed for the characters ranging from days to first floret opening (4.73) to cormels per plant (56.94) followed by Corms/ Plant (37.77), Shoots/ Plant (37.77), Day to Sprouting (20.56), Leaves/ Shoots (18.81), Florets Open At First (19.69), Weight of Corms (18.8), Florets/ Spike (17.35), Durability of Whole Spike
(17.25), Florets Remain Open At A Time (14.47), Plant Height cm (14.09), Rachis Length cm (10.19), Diameter of Corms cm (8.57), Diameter of First Floret (9.88), Days to First Floret Colour Showing (5.30), Days to First Floret Opening (4.87), Days to Last Floret Opening (4.73) and Days to 50\% Heading (3.95) whereas low estimates were observed for Days to 50\% Heading (3.95). Prabhat kumar et al., (2011)

\section{Heritability}

The estimates of heritability from present investigation are presented in table 1 .

Table.1 Phenotypic coefficient and genotypic coefficient of variation, heritability and genetic advance of 20 genotypes in gladiolus at Allahabad region 2013-2014

\begin{tabular}{|c|l|c|c|c|c|c|}
\hline $\begin{array}{c}\text { S. } \\
\text { No. }\end{array}$ & \multicolumn{1}{|c|}{ Observation } & GCV & PCV & $\begin{array}{c}\text { Heritability } \\
\mathbf{h}^{\mathbf{2}}\end{array}$ & G. A. \% & $\begin{array}{c}\text { G. A. } \\
\text { Mean } \\
(\%)\end{array}$ \\
\hline 1 & Weight of Corms & 18 & 18.8 & 91 & 9.92 & 35.37 \\
\hline 2 & Diameter of Corms cm & 4.91 & 8.57 & 32 & 0.28 & 5.81 \\
\hline 3 & Day to Sprouting & 20.25 & 20.56 & 97 & 3.4 & 41.08 \\
\hline 4 & Days to 50\% Heading & 3.84 & 3.95 & 94.3 & 6.13 & 7.68 \\
\hline 5 & $\begin{array}{l}\text { Days to First Floret Colour } \\
\text { Showing }\end{array}$ & 5.33 & 5.3 & 98.7 & 9.69 & 10.9 \\
\hline 6 & Days to First Floret Opening & 4.83 & 4.87 & 98.3 & 9.19 & 9.8 \\
\hline 7 & Days to Last Floret Opening & 4.7 & 4.73 & 98.7 & 10.05 & 9.62 \\
\hline 8 & Durability of Whole Spike & 16.91 & 17.25 & 96.2 & 4.67 & 34.18 \\
\hline 9 & Diameter of First Floret & 9.54 & 9.88 & 94.3 & 2.08 & 19.99 \\
\hline 10 & Florets/ Spike & 17.26 & 17.35 & 97 & 4.81 & 35.02 \\
\hline 11 & Florets Open At First & 18.37 & 19.69 & 87 & 0.7 & 35.31 \\
\hline 12 & Florets Remain Open At A Time & 13.1 & 14.47 & 81.9 & 1.2 & 24.42 \\
\hline 13 & Shoots/ Plant & 34.46 & 37.77 & 83.2 & 1 & 64.76 \\
\hline 14 & Rachis Length cm & 10 & 10.19 & 96.4 & 13.38 & 20.23 \\
\hline 15 & Plant Height cm & 13.96 & 14.09 & 98.2 & 31.89 & 28.51 \\
\hline 16 & Leaves/ Shoots & 8.368 & 10.81 & 60.1 & 1.19 & 13.38 \\
\hline 17 & Corms/ Plant & 34.46 & 37.77 & 83.2 & 1.004 & 64.1 \\
\hline 18 & Cormels/ Plant & 56.64 & 56.94 & 99.1 & 35.48 & 116.29 \\
\hline
\end{tabular}

PCV = Phenotypic coefficient of variation, GCV = Phenotypic coefficient and genotypic coefficient of variation and G. A. Mean $(\%)=$ Genetic advance as $\%$ of mean. 
In the present investigation, the heritability estimates were found to be high (more than $60 \%$ ) for cormels per plant (99.1), Days to Last Floret Opening (98.7), Day to Sprouting (97.00), Florets/Spike (97.00), Days to First Floret Colour Showing (98.7), Days to First Floret Opening (98.3), Durability of Whole Spike (96.2), Plant Height cm (98.2), Rachis Length cm (96.4), Days to 50\% Heading (94.3), Diameter of First Floret (94.3), Weight of Corms (91.00) and Florets Open At First (87.00) Corms/ Plant (83.2) Shoots/ Plant (83.2) Florets Remain Open At A Time (81.9) Leaves/ Shoots (60.1) while Diameter of Corms cm (32.00) showed moderate heritability. The present results on the high heritability for cormels per plant support the earlier findings of Negi et al., (1978, 1982) and Shimelis and Rhandzu (2010).

In the present study, the estimates of heritability in broad sense were computed, which includes additive gene effects.

High value of heritability in broad sense indicates that the character is least influenced by environmental effects.

\section{Genetic advance}

In the present investigation (Table 1), high estimates of genetic advance were observed for cormels per plant (35.48), plant height $(31.89 \mathrm{~cm})$, rachis length $(13.38 \mathrm{~cm})$, days to last florets opening (10.05), weight of corms (9.92), days to first florets colour showing (9.69), days to first florets opening (9.19), days to $50 \%$ heading (6.13), florets per spikes (4.81), durability of whole spikes (4.67), days to sprouting (3.40) and diameters of first florets (2.08) whereas florets remaining open at a time (1.20), leaves per shoot (1.19), corms per plant (1.004), shoots per plant (1.00) florets open at first (0.70) and diameters of corms (0.28) exhibited low genetic advance (Anuradha and Gowda, 1990).
The high heritability coupled with high genetic advance as percentage of mean was observed for Cormels/ Plant (99.1 and 116.29 respectively) indicating that selection for this character is governed by additive gene action and can be improved easily by selection method. The high heritability coupled with high genetic advance for Cormels/ Plant was also reported by Nazir et al., (2002).

PCV was higher than GCV for all the characters under study indicating high degree of environment influence on these characters. The greater differences between GCV and PCV were observed for the characters like Diameter of corm (cm), shoot/plant, Leaves/shoot and corms/plant indicating that these characters were influenced by environmental factors to greater extent while all others characters showed very little difference between GCV and PCV indicating that there was very little environmental influence on them and these characters cannot be improved by providing favorable environment (Mishra et al., 1988). The above finding are broadly in agreement with the earlier findings of Burton (1952).

\section{References}

Allard, R.W., 1960. Principles of plant breeding John Wiley and Sons, inc., New York.

Anuradha, S., and Gowda, J.V.N. 1990. Genetic Variability in Gladiolus Prog. Hort., 22(1-4): 55-59.

Burton, G.W., and Devane, E.H. 1953 Estimating heritability in tall feschue from replicated clonal material. Argon. J., 45: 478-479.

Johnson, H.W., Robinson, H.F. and Comstock, R.E., 1955a. Estimates of genetic and environmental variability in Soyabean. Agron. J., 47: 314-318. 
Nazir, M., 2007. Evaluation of Gladiolus under north Indian plain conditions. $J$. of Asian Hort., (3): 1.

Nazir, M., Bhat, K.L. and Dwivedi, V.K. 2002. Promising gladiolus cultivars: Indian Horticulture, 47(3), 2-27

Negi, S.S., T.V., Sharma, R.S., Raghava, S.P.S. and Srinivisan V.R. 1982. Variability studies in Gladiolus. Indian J. Hort.., 39: 267-272.

Pandey, R.K., D.Sheetal. P.S. Pal, J.Shivani and D.J. Bhat 2010. Performance of gladiolus cultivars under Jammu conditions. J. Res, 9(2): 210-2014.

Prabhat kumar murya, R.K., Binayk Chakraborty, Ramesh Mer mishra and D.S. 2011. Genetic variability and correlation studies in Gladiolus hybrid L. under tarai condition. Annals of Horticulture, 4(2): 140- 146.

Rahul Kumar, Sanjay Kumar, Yadav and Y. C. 2012. Genetic variability, heritability, genetic advance, correlation coefficient and path analysis in gladiolus. Indian J. Hort., 69(3): 369373.

Raj, D. R. L., and Raj, D. 1996. Genetic variability in gladiolus. J. Ornamental Horticulture, 4(1-2): 1-8.

Rashmi, and Sanjay Kumar, 2014. Estimation of genetic variability, correlation and path analysis in gladiolus (Gladiolus species L.). International Journal of Plant Sciences (Muzaffarnagar), 9(1): 186-189.

Shimelis, H., and Rhandzu, S. 2010. Variance components and heritabilities of yield and agronomic traits among cowpea genotypes. Euphytica, 176: 383-389.

Singh, B., and Singh, M. 1990. Studies on variability and genetic advance parameters in gladiolus. Prog. Hort., 19(3-4): 271-275.

\section{How to cite this article:}

Pushpendra Verty, V.M. Prasad, J.P. Collis and Manoj Nazir. 2017. Genetic Variability for Some Quantitative Characters in Gladiolus (Gladiolus grandiflorus L.). Int.J.Curr.Microbiol.App.Sci. 6(9): 750-754. doi: https://doi.org/10.20546/ijcmas.2017.609.092 